\title{
FSHR wt Allele
}

National Cancer Institute

\section{Source}

National Cancer Institute. FSHR wt Allele. NCI Thesaurus. Code C94808.

Human FSHR wild-type allele is located within 2p21-p16 and is approximately $192 \mathrm{~kb}$ in length. This allele, which encodes follicle-stimulating hormone receptor protein, plays a role in the regulation of female gamete generation, hormone signaling and gonad development. Mutation of the gene is associated with both ovarian dysgenesis type 1 and ovarian hyperstimulation syndrome. 